\title{
MONTENEGROSPEUM PEŠIĆ ET GLÖER, 2013: A REPRESENTATIVE OF MOITESSIERIIDAE?
}

\author{
ANDRZEJ FALNIOWSKI ${ }^{1}$, VLADIMIR PEŠIĆ ${ }^{2}$, PETER GLÖER ${ }^{3}$ \\ ${ }^{1}$ Department of Malacology, Institute of Zoology, Jagiellonian University, Gronostajowa 9, 30-387 Cracow, \\ Poland (e-mail: andrzej.falniowski@uj.edu.pl) \\ ${ }^{2}$ Department of Biology, Faculty of Sciences, University of Montenegro, Cetinjski put b.b., 81000 \\ Podgorica, Montenegro \\ ${ }^{3}$ Biodiversity Research Laboratory, Schulstraße 3, D-25491 Hetlingen, Germany
}

The paper is dedicated to the memory of JOZEF ŠTEFFEK (1952-2013), the famous Slovak zoologist and malacologist, partner in our joint research.

ABSTRACT: The paper deals with phylogenetic relationships of recently described Montenegrospeum bogici Pešić et Glöer, 2012 from central Bosnia. The female reproductive system was found to bear two receptacula seminis. Mitochondrial cytochrome oxidase subunit I and nuclear 18S rRNA gene partial sequences were used for the maximum likelihood phylogenetic inference. Morphological and molecular data are congruent: Montenegrospeum does not belong to the Moitessieriidae, and is phylogenetically remote from Bythiospeum; it belongs to the Hydrobiidae, subfamily Sadlerianinae, and its sister taxon is Dalmatinella Radoman, 1973 (bootstrap support 87\%).

KEY WORDS: Truncatelloidea, Moitessieriidae, Sadlerianinae, female reproductive organs, COI, 18S rRNA, molecular phylogeny

\section{INTRODUCTION}

PEŠÍc \& GLÖER (2012) described a new species of Bythiospeum Bourguignat, 1882: B. bogici Pešić et Glöer, 2012 from underground waters of the spring Taban, in the central part of Montenegro. Its description was based on empty shells. Later they (PEŠIĆ \& GLÖER 2013) collected live specimens, and described the lack of eyes and pigment, and the penis with a lobe at its medial part. They considered B. bogici as belonging to a new genus: Montenegrospeum Pešić et Glöer, 2013, still within the family Moitessieriidae Bourguignat, 1863. M. bogici is known from its type locality only (PEŠIĆ \& GLÖER 2013).

The aim of the present paper is to establish phylogenetic relationships of Montenegrospeum, applying two DNA fragments, and reconsidering morphological data.

\section{MATERIAL AND METHODS}

Four specimens of Montenegrospeum bogici from the spring Taban at Montenegro were used: two for morphology, and the other two for molecular work.

Gastropods were dissected using a NIKON SMZ18 stereoscope microscope with dark field.

For DNA, foot tissue was hydrated in TE buffer $(3 \times 10$ min. $)$; then total genomic DNA was ex- tracted with the SHERLOCK extracting kit (A\&A Biotechnology), and the final product was dissolved in $20 \mu \mathrm{l}$ TE buffer. The PCR reaction was performed with the following primers: LCO1490 (5'-GGTCAACAAATCATAAAGATATTGG-3') (FOLMER et al. 1994) and COR722b (5'-TAAACTT CAGGGTGACCAAAAAATYA-3') (WILKE \& DAVIS 2000) for the 
cytochrome oxidase subunit I (COI) mitochondrial gene and SWAM18SF1 5'-GAATGGCTCATTAAATCAGTCGAGGTTCCTT AGATGATCCAAATC-3'), and SWAM18SR1 (5'-ATCC TCGTTAAAGGGTTTAAAGTGTACTCATTC CAATTACGGAGC-3') for the 18S ribosomal RNA gene (ATTWOOD et al. 2003). The PCR conditions were as follows: COI initial denaturation step of $4 \mathrm{~min}$ at $94^{\circ} \mathrm{C}$, followed by 35 cycles of $1 \mathrm{~min}$ at $94^{\circ} \mathrm{C}, 1 \mathrm{~min}$ at $55^{\circ} \mathrm{C}, 2 \mathrm{~min}$ at $72^{\circ} \mathrm{C}$, and a final extension of $4 \mathrm{~min}$ at $72^{\circ} \mathrm{C} ; 18 \mathrm{~S}$ rRNA - initial denaturation step of $4 \mathrm{~min}$ at $94^{\circ} \mathrm{C}$, followed by 40 cycles of $45 \mathrm{~s}$ at $94^{\circ} \mathrm{C}, 45 \mathrm{~s}$ at $51^{\circ} \mathrm{C}$, 2 min at $72^{\circ} \mathrm{C}$ and, after all cycles were completed, an additional elongation step of $4 \mathrm{~min}$ at $72^{\circ} \mathrm{C}$ was performed. The total volume of each PCR reaction mixture was $50 \mu \mathrm{l}$. To check the quality of the PCR products $10 \mu \mathrm{l}$ of the PCR product were ran on $1 \%$ agarose gel. The PCR products were purified using Clean-Up columns (A\&A Biotechnology) and were then amplified in both directions (HILLIS et al. 1996) using BigDye Terminator v3.1 (Applied Biosystems), following the manufacturer's protocol and with the primers described above. The sequencing reaction products were purified using ExTerminator Columns (A\&A Biotechnology); DNA sequences then underwent electrophoresis on an ABI Prism sequencer. The two sequences were deposited in GenBank (Table 1).

In the phylogeny reconstruction, we used 29 truncatelloid taxa sequences, and one of Rissoa, from GenBank (Table 1). Seven of them, used as an out-

Table 1. Taxa used for phylogenetic analyses, with their GenBank Accession Numbers and references

\begin{tabular}{|c|c|c|c|}
\hline Species & 18S GB\# & COI GB\# & references \\
\hline Adrioinsulana conovula (Frauenfeld, 1863) & AF367656 & AF367628 & WILKE et al. (2001) \\
\hline Agrafia wiktori Szarowska et Falniowski, 2011 & JF906758 & JF906762 & SZAROWSKA \& FALNIOWSKI (2011) \\
\hline Alzoniella finalina Giusti et Bodon, 1984 & AF367686 & AF367650 & WILKE et al. (2001) \\
\hline Anagastina zetavalis (Radoman, 1973) & EF070622 & EF070616 & SZAROWSKA (2006) \\
\hline Avenionia brevis (Draparnaud, 1805) & AF367670 & AF367638 & WILKE et al. (2001) \\
\hline Bithynia tentaculata (Linnaeus, 1758) & AF367675 & AF367643 & WILKE et al. (2001) \\
\hline Boleana umbilicata (Kuščer, 1932) & JX982797 & JX982795 & FALNIOWSKI \& SZAROWSKA (2012) \\
\hline Bythinella austriaca (Frauenfeld, 1857) & AF212917 & FJ545132 & FALNIOWSKI et al. (2009) \\
\hline Bythiospeum sp. & AF367664 & AF367634 & WILKE et al. (2001) \\
\hline Dalmatinella fluviatilis Radoman, 1973 & KC344539 & KC344541 & FALNIOWSKI \& SZAROWSKA (2013) \\
\hline Daphniola graeca Radoman, 1973 & EF070624 & EF070618 & SZAROWSKA (2006) \\
\hline Dianella thiesseana (Kobelt, 1878) & AY676125 & AY 676127 & SZAROWSKA et al. (2005) \\
\hline Graecoarganiella parnassiana Falniowski et Szarowska, 2011 & JN202341 & JN202348 & FALNIOWSKI \& SZAROWSKA (2011) \\
\hline Graziana alpestris (Frauenfeld, 1863) & AF367673 & AF367641 & WILKE et al. (2001) \\
\hline Grossuana codreanui (Grossu, 1946) & EF061916 & EF061919 & SZAROWSKA et al. (2007) \\
\hline Hauffenia tellinii (Pollonera, 1898) & AF367672 & AF367640 & WILKE et al. (2001) \\
\hline Heleobia dalmatica (Radoman, 1974) & AF367661 & AF367631 & WILKE et al. (2001) \\
\hline Horatia klecakiana Bourguignat, 1887 & KJ159127 & KJ159128 & SZAROWSKA \& FALNIOWSKI (2014) \\
\hline Hydrobia acuta (Draparnaud, 1805) & AF367680 & AF278808 & WILKE \& DAVIS (2000) \\
\hline Islamia piristoma Bodon et Cianfanelli, 2001 & AF367671 & AF367639 & WiLKE et al. (2001) \\
\hline Lithoglyphus naticoides (C. Pfeiffer, 1828) & AF367674 & AF367642 & WILKE et al. (2001) \\
\hline Marstoniopsis insubrica (Küster, 1853) & AF367676 & AY027813 & FALNIOWSKI \& WILKE (2001) \\
\hline Montenegrospeum bogici (Pešić et Glöer, 2012) & KM875509 & KM875510 & present study \\
\hline Pseudamnicola lucensis (Issel, 1866) & AF367687 & AF367651 & WILKE et al. (2001) \\
\hline Pyrgula annulata (Linnaeus, 1767) & AY676124 & AY341258 & SZAROWSKA et al. (2005) \\
\hline Radomaniola callosa (Paulucci, 1881) & AF367685 & AF367649 & WiLKE et al. (2001) \\
\hline Rissoa labiosa (Montagu, 1803) & AY676126 & AY676128 & SZAROWSKA et al. (2005) \\
\hline Sadleriana fluminensis (Küster, 1853) & AF367683 & AY273996 & WILKE et al. (2001) \\
\hline Trichonia kephalovrissonia Radoman, 1973 & EF070630 & EF070619 & SZAROWSKA (2006) \\
\hline Ventrosia ventrosa (Montagu, 1803) & AF367681 & AF118335 & WILKE \& DAVIS (2000) \\
\hline Vinodolia fiumana Radoman, 1973 & KF359899 & KF359900 & SZAROWSKA et al. (2013) \\
\hline
\end{tabular}


group, represented the main non-hydrobiid lineages within the Rissooidea (WILKE et al. 2001); the other six taxa represented the Hydrobiinae (including "Pyrgulinae": SZAROWSKA et al. 2005). The remaining taxa were chosen to represent all the main lineages within the European Sadlerianinae (SZAROWSKA 2006).

The COI sequences were aligned by eye using BioEdit 5.0.0 (HALL 1999). For 18S, an initial alignment was performed using CLUSTALX 1.82 (THOMPSON et al. 1997) and edited with MACCLADE (MADDISON \& MADDISON 2002). Mutational saturation for the COI dataset was examined by plotting the numbers of transitions and transversions for all the codon positions together, and for the 3rd position separately, against the percentage sequence divergence, using DAMBE 5.2.9 (XIA 2000). We also used DAMBE 5.2.9 to perform the saturation test (XIA et al. 2003). It revealed a significant degree of saturation in the third position of the sequences. In truncatelloids, COI approaches saturation with about $18.6 \%$ or 120 nucleotide differences (DAVIS et al. 1998), which seems to happen after approximately 10 million years. However, to avoid a substantial loss of information in the case of closely related species, this position was not excluded from the dataset and it was used for the analysis. In fact, the analysis carried out on the 2nd and 3rd position only resulted in similar deep phylogeny, but with several polyto- mies within more terminal nodes. It should be noted that the saturation test of XIA et al. (2003), for symmetrical tree, and the proportion of invariable sites I $=0.49$, resulted in Iss $=0.4606$, Iss.c $=0.7060, p=$ 0.000 , thus showing little saturation.

Initially, we performed phylogeny reconstruction for $18 \mathrm{~S}$ and COI data separately, using the maximum likelihood (ML) technique. Next, the partition homogeneity test (FARRIS et al. 1995) was performed (1,000 replicates) with PAUP*4.0b10 (SWOFFORD 2002), to check whether the two genes could be analysed together. Since $p>0.792$, the maximum likelihood heuristic search was then run for the combined molecular data. Following the recommendations of POSADA \& BUCKLEY (2004) and SOBER (2002), the best model for each dataset was chosen using the Akaike Information Criterion (AIC) and the Bayesian Information Criterion (BIC); both chose the same model: Tamura-Nei $+\Gamma+$ I (NEI \& KUMAR 2000). We performed ML analyses in PAUP* and used a heuristic search strategy with stepwise addition of taxa, 10 random-sequence addition replicates, and tree-bisection-reconnection (TBR) branch swapping (SWOFFORD et al. 1996), and with MEGA5.10 (TAMURA et al. 2011). Nodal support was estimated using the bootstrap (BS) approach (FELSENSTEIN 1985). Bootstrap values for ML trees were calculated using 10,000 bootstrap replicates, with MEGA5.10 and the same model parameters as for ML analysis.

\section{RESULTS AND DISCUSSION}

The female reproductive organs of the two studied specimens, with two seminal receptacles ( $\mathrm{rs}_{1}$ and $\mathrm{rs}_{2}$ : RADOMAN 1973, 1983) were characteristic of numerous genera of the Sadlerianinae Radoman, 1973, certainly not of the Moitessieriidae Bourguignat, 1863 (SZAROWSKA 2006). The penis with a lobe on the left side of its median part (PEŠÍć \& GLÖER 2013) was also similar to the ones characteristic of several genera of the Sadlerianinae. In fact, its appearance is simple, not unique. A similar penis could be found in Dalmatinella fluviatilis Radoman, 1973 (FALNIOWSKI \& SZAROWSKA 2012).

Two sequences of COI were identical, the same concerns two sequences of $18 \mathrm{~S}$. The molecular tree based on the two loci (Fig. 1) confirmed general conclusions based on the morphology: Montenegrospeum does not belong to the family Moitessieriidae, thus being phylogenetically remote from Bythiospeum, and belongs to the family Hydrobiidae Troschel, 1857 (bootstrap support 97\%), and to the subfamily Sadlerianinae Radoman, 1973 (bootstrap support $73 \%$ ). In the tree, Dalmatinella is the sister taxon of Montenegrospeum (bootstrap support 87\%). Considering the genetic distance between the two

taxa, within the range typical of inter-genus relationships within the Truncatelloidea, Montenegrospeum could be considered a distinct genus, as proposed by PEŠIĆ \& GLÖER (2013).

The results presented above may be a good illustration of the already well known fact that neither shell nor penis character states (especially if only the habitus of the latter is considered) could be used as the only basis of classification within the Truncatelloidea. Considering that most of the numerous nominal species of Bythiospeum recorded from Europe are known as empty shells only - since the snails inhabit strictly subterranean, running or interstitial waters and only their shells could be found on the surface - one could expect that phylogenetic relationships within this group (including Paladilhiopsis Pavlovic, 1913 as well) may be complex, and the genus is polyphyletic.

\section{ACKNOWLEDGEMENTS}

The study was supported by a grant from the National Science Centre (2012/05/B/NZ8/00407) to MAGDALENA SZAROWSKA. 


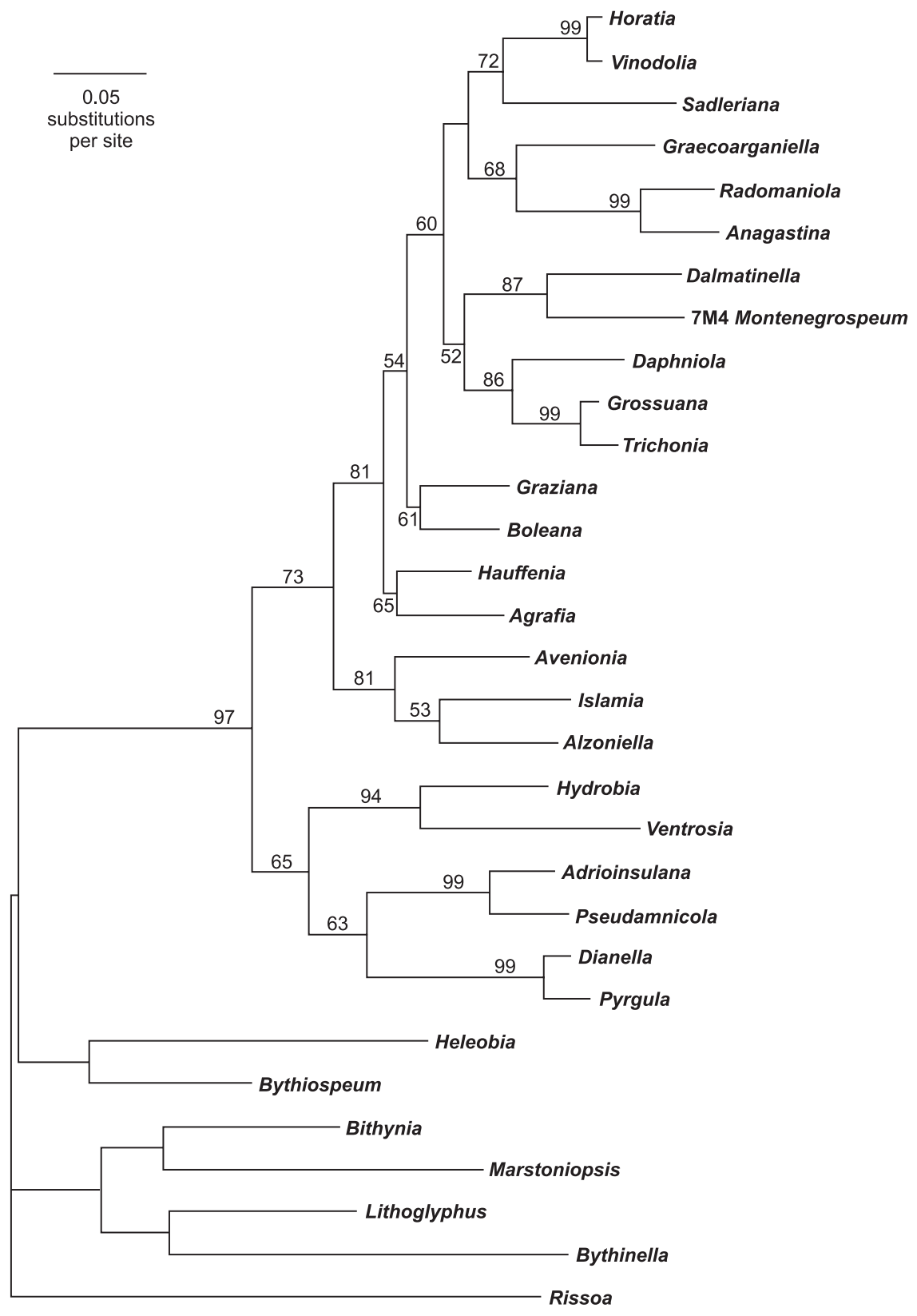

Fig. 1. Maximum likelihood tree of the two concatenated sequences (18S and COI), bootstrap supports (10,000 replicates) given if $>50 \%$

\section{REFERENCES}

Attwood S. W., Ambu S., Meng X.-H., Upatham E. S., XU F.-S., Southgate V. R. 2003. The phylogenetics of Triculine snails (Rissooidea: Pomatiopsidae) from South-East Asia and southern China: historical biogeography and the transmission of human schistosomiasis. J. Mollus. Stud. 69: 263-271. http://dx.doi. org/10.1093/mollus/69.3.263

DAVIS G. M., WILKE T., SPOLSKY C., QIU C.-P., QIU D.-C., XiA M.-Y., ZHANG Y., ROSENBERG G. 1998 Cytochrome oxidase I-based phylogenetic relationships among the Pomatiopsidae, Hydrobiidae, Rissoidae and Truncatelidae (Gastropoda: Caenogastropoda: Rissoacea). Malacologia 40: 251-266.

FALNIOWSKI A., SZAROWSKA M. 2011. A new genus and new species of valvatiform hydrobiid (Rissooidea; Caenogastropoda) from Greece. Moll. Res. 31: 189-199.

FALNIOWSKI A., SZAROWSKA M. 2012. Phylogenetic position of Boleana umbilicata (Kuščer, 1932) (Caenogastropoda: Rissooidea). Folia Malacol. 20: 265-270. http://dx.doi. org/10.2478/v10125-012-0022-2

FALNIOWSKI A., SZAROWSKA M. 2013. Phylogenetic relationships of Dalmatinella fluviatilis Radoman, 1973 
(Caenogastropoda: Rissooidea). Folia Malacol. 21: 1-7. http://dx.doi.org/10.12657/folmal.021.001

FALNIOWSKI A., SZAROWSKA M., SIRBU I. 2009. Bythinella Moquin-Tandon, 1856 (Gastropoda: Rissooidea: Bythinellidae) in Romania: species richness in a glacial refugium. J. Nat. Hist. 43: 2955-2973. http://dx.doi. org/10.1080/00222930903359636

FALNIOWSKI A., WILKE T. 2001. The genus Marstoniopsis (Gastropoda: Rissooidea): intra- and intergeneric phylogenetic relationships. J. Mollus. Stud. 67: 483-488. http://dx.doi.org/10.1093/mollus/67.4.483

FARris J. S., KÄllersJö M., Kluge A. G., Bult C. 1995. Testing significance of incongruence. Cladistics 10: 315-319. http://dx.doi.org/10.1111/j.1096-0031.1994. tb00181.x

FELSENSTEIN J. 1985. Confidence limits on phylogenies: an approach using the bootstrap. Evolution 39: 783-791. http://dx.doi.org/10.2307/2408678

Folmer O., Black M., HoeH W., Lutz R. A., VRijenhoeK R. C. 1994. DNA primers for amplification of mitochondrial cytochrome $\mathrm{c}$ oxidase subunit I from diverse metazoan invertebrates. Mol. Mar. Biol. Biotechnol. 3: 294-299.

HALl T. A. 1999. BioEdit: a user-friendly biological sequence alignment editor and analysis program for Windows 95/98/NT. Nucleic Acids Symp. Ser. 41: 9598.

Hillis D. M., MABLE B. K., LARSON A., DAVIS S. K., ZiMmER E. A. 1996. Nucleic acids IV: sequencing and cloning. In: Hillis D. M., MORITZ C., MABLE B. K. (eds). Molecular systematics. 2 edn. Sinauer Associates Inc., Sunderland, Massachusetts, pp. 321-381.

MADDisON D. R., MADDiSON W. P. 2002. MACCLADE. Ver. 4.05. [Computer software and manual]. Sinauer Associates Inc., Sunderland, Massachusetts.

NeI M., Kumar S. 2000. Molecular evolution and phylogenetics. Oxford University Press, Oxford, UK - New York.

PEŠIĆ V., GLÖER P. 2012. A new species of Bythiospeum Bourguignat, 1882 (Hydrobiidae, Gastropoda) from Montenegro. Biologica Nyssana 3: 17-20.

PEŠIĆ V., GLÖER P. 2013. Montenegrospeum, a new genus of hydrobiid snails (Gastropoda: Risooidea) from Montenegro. Acta zool. bulg. 65: 565-566.

POSADA D., BUCKLEY T. R. 2004. Model selection and model averaging in phylogenetics: advantages of Akaike Information Criterion and Bayesian approaches over Likelihood Ratio Tests. Syst. Biol. 53: 793-808. http:// dx.doi.org/10.1080/10635150490522304

RADOMAN P. 1973. New classification of fresh and brackish water Prosobranchia from the Balkans and Asia Minor. Posebna Izdanja, Prirodn. Mus. Beograd 32: 1-30.

RADOMAN P. 1983. Hydrobioidea a superfamily of Prosobranchia (Gastropoda). I Systematics. Serbian Academy of Sciences and Arts, Monographs 547, Department of Sciences 57: 1-256.

SOBER E. 2002. Instrumentalism, parsimony, and the Akaike framework. Philos. Sci. 69: 112-123. http://dx. doi.org/10.1086/341839
SWOFFORD D. L. 2002. PAUP*-Phylogenetic analysis using parsimony (* and other methods). Ver. 4. [Computer software and manual]. Sinauer Associates Inc., Sunderland, Massachusetts.

SwOFFord D. L., Olsen G. J., WAdDEll P. J., Hillis D. M. 1996. Phylogenetic inference. In: HILlis D. M., MORITZ C., MABLE B. K. (eds), Molecular systematics. 2 ed. Sinauer Associates Inc., Sunderland, Massachusetts, pp. 407-514.

SZAROWSKA M. 2006. Molecular phylogeny, systematics and morphological character evolution in the Balkan Rissooidea (Caenogastropoda). Folia Malacol. 14: 99168. http://dx.doi.org/10.12657/folmal.014.014

SZAROWSKA M., FALNIOWSKI A. 2011. An unusual, flagellum-bearing hydrobiid snail (Gastropoda:Rissooidea: Hydrobiidae) from Greece,with descriptions of a new genus and a new species. J. Nat. Hist. 45: 2231-2246. http://dx.doi.org/10.1080/00222933.2011.591067

SZAROWSKA M., FALNIOWSKI A. 2014. Horatia Bourguignat, 1887: is this genus really phylogenetically very close to Radomaniola Szarowska, 2006 (Caenogastropoda: Truncatelloidea)? Folia Malacol. 22: 31-39. http://dx. doi.org/10.12657/folmal.022.003

SZAROWSKA M., FALNIOWSKi A., RIEDEL F., WiLKe T. 2005. Phylogenetic relationships of the subfamily Pyrgulinae (Gastropoda: Caenogastropoda: Hydrobiidae) with emphasis on the genus Dianella Gude, 1913. Zootaxa 891: $1-32$.

SZAROWSKA M., GRZMIL P., FALNIOWSKI A., SIRBU I. 2007. Grossuana codreanui (Grossu, 1946) and the phylogenetic relationships of the East Balkan genus Grossuana (Radoman, 1973) (Gastropoda: Rissooidea). Hydrobiologia 579: 379-391. http://dx. doi.org/10.1007/s10750-006-0530-4

SZAROWSKA M., HOFMAN S., FALNIOWSKI A. 2013. Vinodolia fiumana Radoman, 1973 (Caenogastropoda: Rissooidea): rediscovery and relationships of a species presumed extinct. Folia Malacol. 21: 135-142. http:// dx.doi.org/10.12657/folmal.021.017

Tamura K., Peterson D., Peterson N., Stecher G., Nei M., KUMAR S. 2011. MEGA5: Molecular evolutionary genetics analysis using maximum likelihood, evolutionary distance, and maximum parsimony method. Mol. Biol. Evol. 28: 2731-2739. http://dx.doi.org/10.1093/ molbev/msr121

Thompson J. D., Gibson T. J., Plewniak F., JeAnMougin F., Higgins D. G. 1997. The ClustalX windows interface: flexible strategies for multiple sequence alignment aided by quality analysis tools. Nucleic Acids Res. 24: 4876-4882. http://dx.doi.org/10.1093/nar/25.24.4876

WiLKE T., DAVIS G. M. 2000. Infraspecific mitochondrial sequence diversity in Hydrobia ulvae and Hydrobia ventrosa (Hydrobiidae: Rissoacea: Gastropoda): Do their different life histories affect biogeographic patterns and gene flow? Biol. J. Linn. Soc. 70: 89-105. http://dx.doi. org/10.1111/j.1095-8312.2000.tb00202.x

Wilke T., DAVIS G. M., FALNIOWSKI A., GIUSTI F., BODON M., SZAROWSKA M. 2001. Molecular systematics of Hydrobiidae (Gastropoda: Rissooidea): testing monophyly and phylogenetic relationships. 
Proc. Acad. Nat. Sci. Philadelphia 151: 1-21. http:// dx.doi.org/10.1635/0097-3157(2001)151[0001:MSOHMG]2.0.CO;2

XIA X. 2000. Data analysis in molecular biology and evolution. Kluwer Academic Publishers, Boston, Dordrecht \& London.

XiA X., Xie Z., SAlemi M., Chen L., WANG Y. 2003. An index of substitution saturation and its application. Mol.
Phyl. Evol. 26: 1-7. http://dx.doi.org/10.1016/S10557903(02)00326-3

Received: June 18th, 2014

Revised: July 24th, 2014

Accepted: July 25th, 2014

Published on-line: October 29th, 2014 